\title{
Working at a marginal 'career': the case of UK social science contract researchers
}

\author{
Jacquelyn Allen Collinson
}

\section{April 2003}

University of Gloucestershire Leisure \& Sport Research Unit Oxstalls Campus Gloucester GL2 9HW 
Tel: 01452876664

Email: jcollinson@glos.ac.uk 


\title{
Occupational Identity on the Edge: Social Science Contract Researchers in Higher Education
}

\author{
Abstract
}

Contract researchers constitute a significant occupational group within the UK higher education system, and the products of their labour are crucial to the research profile of the institutions in which they work and to the sector as a whole.. Given the 'marginality' of the contract researcher role, with its attendant insecurities and inferior employment conditions in comparison with 'permanent' faculty, it is perhaps not surprising that relatively few individuals manage to sustain any continuity of employment resembling a career path. The fact that some researchers do succeed in achieving this is therefore worthy of investigation. This paper examines and charts some of the ways in which contract researchers manage their everyday work routines and construct a presentation of self in order to maximise opportunities for 'staying in the game'. 


\section{Occupational Identity on the Edge: Social Science Contract Researchers in Higher Education}

\section{Introduction}

Within the wider economy, human capital and post-Fordist theories (Harvey, 1989) concerning the contemporary world of work have been influential inter alia in the formulation of, and demand for a 'flexible' workforce (Barlow, 1995). 'Flexibility', however, is a problematic concept and, as has been noted (see for example, Rubery and Grimshaw, 2003), flexibility along one dimension may produce rigidity and constraint on another, particularly for employees. Some employers have sought to maximise flexibility and reduce wages by increasing casual, part-time and contract work. This kind of employment constitutes an increasingly important feature of the labour markets of the leading capitalist countries (Lane, 1989; Mayne et al, 1996), and has proliferated within the British higher education sector (Parker and Jary, 1995; Mclnnis, 2000). Indeed, recent decades have witnessed the increasing use of fixed-term and part-time labour within higher education, to a point where about $50 \%$ of academic staff are currently employed on fixedterm contracts (Bryson and Barnes, 2000). In the UK, numbers of fixed- 
term researchers have been on the increase since the 1970s, and research indicates that in 1998 there were 28,596 staff employed on research grades, a staggering $96 \%$ of whom were on hourly-paid or fixed-term contracts (Bryson and Barnes, 2000:194-199). As Kogan et al (1994: 53) have noted, this increased casualisation of academic labour has been driven to some extent by the need for universities and colleges to reduce labour costs. The move towards a more flexible and cheaper workforce is largely a response to governmental resource restrictions and the need to cope with increased student numbers (Kogan et al 1994).

In 1996 a Concordat on the career management of contract researchers in UK universities was published (CVCP, 1996). Subsequently, concerns over poor career structures and prospects for postdoctoral researchers, specifically in science, engineering and technology, and the consequent problems of recruitment and retention, featured strongly in a recent UK Government review of the employment position of scientists and engineers (Roberts, 2002). Although the review focussed upon contract researchers in science, engineering and technology, many of the problems encountered in these disciplines are duplicated within the social sciences. 
In recent years academic interest in higher education contract researchers has developed, as evidenced by a range of literature reviews (for example: Patrick, 1998; Bryson and Barnes, 2000; Freedman et al, 2000); the research being principally in the form of surveys charting the inferior pay and conditions characteristic of these researchers (see Bryson and TulleWinton, 1994). The surveys demonstrate the inferior status of contract researchers when compared with 'permanent' academic staff, indicate that contracts are getting shorter, and that the occupational structure of contract research reflects wider social disparities, with women under-represented at the senior research grades and over-represented at more junior levels (Court et al, 1996; Bryson, 1999).

Despite this recent attention, the non survey-based research literature on contract researchers is not extensive. Some material touches on the management of contract researchers (for example, Roth, 1966; Wakeford, 1985; Burgess, 1994). A limited amount of qualitative material examines contract researchers' occupational lives (for example, Stronach and Macdonald, 1991; Whiston, n.d.) and is supplemented by a small number of personal accounts of life as a contract researcher (see for example, Scott 
and Porter, 1983, 1984; Scott, 1985; Pole, 1995; Pirrie, 1997).

In sum, although contract researchers represent a substantial and important sector of the labour force within higher education, very little is known about the actual routines and complexities of their occupational lives (AllenCollinson and Hockey, 1998; Allen-Collinson, 2000). As various commentators (Abbas and McLean, 2001; Blaxter et al, 1998; Delamont et al, 1994) have observed, knowledge about the reproduction of academic occupational culture is sparse, and the limited amount of published work has concentrated almost exclusively upon teaching staff (Delamont, 1996; Edwards, 2000; Hey, 2001).

\section{The Research}

With the aim of addressing this lacuna, qualitative research was initiated, involving interviews with 61 social science contract researchers, 59 of whom were employed at 11 United Kingdom universities, one was currently unemployed, and one, with considerable experience within the UK, was employed at an overseas university at the time of interview. The profile of the researchers studied is given in Table 1. Initially judgment sampling 
(Burgess, 1984), also termed criteria sampling (Creswell, 1998) was used to select the group. Snowball sampling (Creswell, 1998) supplemented the initial trawl resulting in a selection of diverse sites, covering both traditional academic departments $(n=10)$ and specialist research centres $(n=10)$, in the fields of sociology, socio-legal studies, social work, social policy, politics, psychology, planning and education. Various of the centres operated with a multi-disciplinary framework. The purpose of the study was not to generate statistical generalisations but to explore the complexities of contract researchers' working practices and subjective experiences of contract work. In common with much qualitative analysis, extrapolation from the data relies on 'the validity of the analysis rather than the representativeness of the events' (Mitchell, 1983: 190). Interviews were in-depth, semi-structured, tape-recorded, and designed to gather data on researchers' work lives, their motives, aspirations, coping strategies, learning processes, and conceptions of identity. Those interviewed ranged from novice research assistants on their first contract, to senior research fellows with over a decade of experience; those on relatively long-term contracts (3 years or more) to those employed on a daily, even hourly rate. 
Table 1 - to be inserted around here

Data analysis was carried out via the constant comparative method (Glaser, 1993), with detailed coding permitting the generation of key thematic categories and sub-categories. This process of analysis was repeated until no new categories, in terms of social processes, practices, and conceptions, were emerging from the data (Creswell, 1998).

\section{A Career?}

Given the 'marginality' (Scott, 1985; Bilson, 1988) of the contract researcher role, with its insecurities and inferior material conditions in comparison to 'permanent' academic posts, it is perhaps not surprising that relatively few individuals manage to sustain any continuity of employment resembling a career path (Bryson and Barnes, 2000). The fact that some researchers do manage to achieve this is therefore worthy of investigation. As can be seen from Table 1, of those interviewed, 20 had 6 years or more of contract research experience. These individuals had evidently learnt how to sustain some employment track, and the primary purpose of this paper is to examine this achievement. Comparison of interview transcripts from both 
inexperienced and 'veteran' researchers has generated a mosaic (Becker, 1977) of their experience.

Evetts (1992) has emphasized the need to examine careers from the perspective of the individual, as a subjective experience. Although in an everyday sense, the idea of a 'career' in contract research may appear somewhat risible, this is not so if Hughes' (1959: 457) classic definition is applied: 'a career consists in one sense of moving - in time and hence with age - within the institutional system in which the occupation exists'. This does not mean of course that there is any neat correlation between time served in the occupation and the development of the knowledge and skills required for contract research praxis. After all, work occurs in specific contexts, within which demands and opportunities will inevitably vary. In the case of contract researchers, the resources available for the development of craft knowledge and skills will differ, for example between academic departments employing just a solitary researcher, and research centres with large (relative to the social sciences) teams of researchers. Clearly, within the latter, more opportunities arise for the development and transmission of research expertise. Occupational time needs therefore to be linked to specific contexts 
and sets of experiences in order for the researcher's capacity fully to develop. Acknowledging these complexities, this paper seeks to portray some of the occupational learning processes during career progression. It should be noted that the focus of the paper centres not upon the technical skills in which researchers became practised, such as research design, data collection and analysis, but rather the amalgam of more 'tacit', private, or as some have termed it 'indeterminate' (Polanyi, 1983; Gerholme, 1990; Delamont and Atkinson, 1995) knowledge and practices which are developed. 'Indeterminacy' has been defined as the 'elements of occupational competence that are dependent upon tacit knowledge. They are not susceptible to codification and representation through explicit recipes' (Delamont and Atkinson, 1995: 96). Despite the 'unofficial', informal nature of such knowledge and practices, they nonetheless often prove crucial for the successful completion of occupational tasks.

\section{Structural adaptation}

Entering a new occupation usually involves some degree of 'reality shock' (see Dornbusch, 1955) in which novices' expectations of role performance are contrasted, sometimes starkly, with actual occupational demands. Usually, 
pre-socialisation (Berger and Luckman, 1976), in terms of formal or informal knowledge about organisational behaviour, is less than adequate to prepare newcomers fully for the reality of their new daily work routines. During their initial contract, researchers struggle to orientate themselves and to cope with the new occupational milieu, and various biographical elements may help or hinder their adaptation.

The 'biographical baggage' of the researchers studied was somewhat diverse with many interviewees having entered contract research direct from a first or higher degree, others from professions such as social work, teaching and law, whilst a small minority $(n=5)$ had previously worked in secretarial and technician roles within higher education. The research experience of the great majority of these researchers could be conceptualised as 'traditional' in terms of their academic training. Coming to terms with the constraints of contract research, particularly sponsor-imposed agenda and deadlines, required a fundamental readjustment, particularly for those entering the occupation direct from a degree. As one Research Fellow indicated, recalling novice days: 
'The business of doing contract research demands you quickly develop a very pragmatic, even instrumental relationship to gaining knowledge... It's all about finding out things to change things, and to meet the sponsor's needs. I struggled with that because my doctorate had allowed me much more freedom.'

(Research Fellow, Department)

In contrast, the small number of researchers who might be deemed 'nontraditional' had no background of disciplinary knowledge acquisition, and did not appear to encounter this kind of difficulty. In fact they articulated very pragmatic attitudes towards knowledge acquisition even at initial entry.

For many of the novice researchers the role of contract researcher represented their first real engagement with the world of work, and consequently with managers who placed demands and imposed deadlines. These employment relationships were agreed to be qualitatively different from earlier relationships with, for example, tutors or research degree supervisors. Propelling the demands of research directors and managers of course were those of sponsors, for the managers were keenly aware that future funding 
depended upon the timely completion of projects. Awareness of these new responsibilities was sometimes acute amongst new researchers:

'This year has been a bit of a wake-up call!... I've realised that the projects I have been working on depend on me, because if the fieldwork falls down, the projects will, and I'm the one doing the fieldwork. It's become much more serious than the previous year when I was doing my MSc, because I'm now responsible to the Prof and he is responsible for getting the projects to the agency on time.'

(Research Assistant, Department)

For all novice researchers, regardless of background, knowledge of the cyclical work processes, or 'event-based cycle' (Clark, 1985), peculiar to contract research, had to be acquired. This cycle can be seen to consist primarily of: gaining research contracts, timely completion, and gaining further contracts. Moreover, the cycle operates within an overall temporal framework within which the passage of work-time is commodified, quantified, and attributed worth (Hassard, 1989; Lee and Liebenau, 1999). Hence, for employers, research time is money (Loft, 1995); a perspective researchers 
also learn to adopt, as research time ultimately means salary. The cycle involves transition through the routine phases of research work, for example: project design, data collection and analysis, and so on. Researchers must not only develop and deploy research techniques, but also, importantly, learn to assess what the cycle demands of them in terms of cognitive and also emotional effort.

The emotional elements of each contract cycle were particularly interesting to examine. Understandably, upon initial engagement, relief was the overwhelming response of researchers, happy that the occupational future had once more been secured, however temporarily. Researchers often used the term 'honeymoon' to describe this initial phase, during which they become cognitively immersed in the new project. Apart from those on the very shortest of contracts, it is during this period that feelings of economic insecurity are most far removed, and positive self-worth and intellectual absorption predominate. The second phase usually begins around the midway point of the contract, and was conceptualised by researchers overwhelmingly as 'pressured'. This period was found usually to extend until the project report was submitted to sponsors, and is characterised by 
increasing anxiety over the intellectual demands of the work and its timely completion. Simultaneously, worries over obtaining a further contract begin to creep in, with the spectre of economic instability looming large. Within this phase of the researchers' event-based cycle, time seems to escape at an alarming rate, both in terms of the sponsor's fast-approaching deadline and the expiry of the researcher's own personal contract. Maximum effort must be exerted in pursuit of the next contract.

Relief, intellectual absorption, pressure and insecurity are some of the experiences which mark the event-based cycle of contract researchers' time. If they are fortunate, another contract is secured and so another cycle commences. Researchers acquire a practical understanding of the cycle, its rhythms, speed, length and sequencing of activities (see Lauer, 1981: 28ff) and also a sensitivity to the practicalities and likely intensities of cognitive and emotional effort demanded at particular points:

'This is my first post as a contract researcher, and it's been a bit of a salutary introduction...Well, it seems to me it's a bit like a business because you have to provide a product to those who are paying for it, 
so there's all that concern about meeting sponsors' deadlines... You cannot ask for an extension if you want any more contracts. It all got very hectic towards the end. (Research Associate, Centre)

Depending on their own particular biographical 'baggage', novices have to work to a greater or lesser extent to adapt to the structural features of their new employment, including its contractual, pragmatic and commodified nature, which may contrast starkly with their prior experience of academia and the pursuit of knowledge for more 'pure' and scholarly reasons.

\section{Interactional integration}

Once contract researchers adapt to the pressurized, commodified, and increasingly entrepreneurial nature of their work (Slaughter and Leslie, 1997), it quickly becomes apparent that securing the occupational future will require a high degree of initiative on their part, in order to avoid unemployment. Novice researchers must accumulate and operationalise certain kinds of tacit knowledge in order to forestall such a negative possibility. 
A factor of primary importance in this learning process is a researcher's relationship with her or his peers, which may hold the key to maintaining employment and building the first steps in a career. As noted above, the resource of peer support is largely dependent upon the location in which the researcher finds her/himself. Of those interviewed, 49 researchers worked in locations with some degree of peer support, although the size of the peer network might vary over time. In contrast, 11 researchers worked in locations lacking any such networks. Here, the employment of researchers was at best sporadic and mainly confined to solitary researchers, for whom isolation was a striking feature of the work experience.

In departments where a considerable amount of research activity is normal, with numerous researchers at various points of their contracts, knowledge of research opportunities constitutes a highly valued resource which circulates surprisingly freely between colleagues who might in some contexts be deemed to be competitors. In these contexts, mutual aid consists not only of imparting information about possibilities of work, but also, for example, inviting peers to collaborate on projects, or even 
nominating colleagues to sponsors. In the main, these kinds of 'gifts' (Mauss, 1967) of work are smaller projects or discrete activities on a project, such as data analysis or interviewing. Via this mutual aid, researchers are able to 'tide themselves over' until better contractual opportunities arise. This was particularly so in certain of the large research centres visited, where part of the researcher's contractual obligations included personal income targets. The giving and receiving of such gifts helped to secure the material future, and thus reinforced the value and meaning of the practice to researchers (see Bourdieu, 1977). Such gift exchange has both economic and symbolic dimensions which reinforce each other, helping to establish and sustain solidarity in the face of insecurity. In work locations bereft of a critical mass of research colleagues, attempts to maintain a career were found to be much more problematic, and so knowledge about the importance of peer networks inevitably influenced the preferred employment options of researchers. The comments of one Research Fellow are illustrative of many:

'Where you do not want to end up is in an isolated situation... I try and avoid ordinary departments now, it's ok if there is a research centre 
within a department, because you then have colleagues around, and that means all sort of stuff comes to you ... I started off doing this kind of research as the sole research assistant in a department and at the end of the contract, I got three months unemployment as a bonus!' (Research Fellow, Centre)

Researchers also developed a pragmatic appreciation of the importance of particular forms of interaction with research managers or directors, who had the all-important power to extend work contracts. As Wunsch (1993: 353) notes: 'scholarship on successful careers provides evidence that success often depends not only on hard work but on the ability to selfpromote'. The interviews revealed that successful researchers learnt to exercise this combination early on in their work experience. The practice of self-promotion, and indeed the awareness of the need to self-promote, developed differentially amongst researchers, and it was clear that some researchers were more aware of the significance of this unofficial activity (see Kleinman, 1983), noting the importance of 'cues' or pointers provided by other more experienced colleagues, for example: 
'On my first couple of contracts I learnt a lot about research methods and the pattern of working in this peculiar trade. On my third I learnt I needed to ensure that people noticed me... that was pointed out to me by someone who was much more experienced. He was leaving the Centre and told me that to stay here I needed to keep myself in the Research Director's mind.' (Research Fellow, Centre)

Acting on this awareness constitutes the 'strategic work' (Slaughter and Leslie, 1997) necessary to sustain and prolong one's employment. In essence this requires of researchers a degree of 'performance' to ensure that they are viewed in a positive light by research directors and other members of staff. Such presentation of self (Goffman, 1959) of course includes being seen to be proficient in the technical activities of research, but additionally, the research must exhibit commitment to, and involvement in, numerous activities other than purely research-related ones. Thus researchers involve themselves in a range of extra activities: teaching, conference organisation and attendance, the coordination of seminars and workshops, committee membership, the hosting of visitors, to name a few. 
By engagement in these activities over and above their research duties, researchers 'signpost' to those in positions of power that their commitment (Becker, 1977) extends beyond mere contractual obligations. By being recognized as committed, researchers build a positive reputation, and hope to benefit by way of future employment opportunities. Experienced researchers certainly become sensitised to the need for careful impressionmanagement and self-presentation, as one indicated:

'A lot of researchers have passed through this Centre since I began to work here ... I suppose I have always been trying to work out how I can stay here. So from early on I never hesitated at working late when the situation demanded ... It's also the little things like volunteering to chair the IT group. Really it's a package of things which you hope are all saying that you are a safe pair of hands, and good to have around for yet another contract.'

(Research Fellow, Centre)

In sum, once the full realisation of the fundamental insecurity of their occupational position dawned, those researchers who sought to continue in 
research began to assimilate vital informal knowledge and to develop certain strategies which helped sustain employment. This involved cooperation with peers, and attempts to influence those with the power to rehire. Researchers strove to maintain interactional integration at their home-base, by ensuring they were part of informal peer networks of support, and also by being dependable - and visible - components of the more formal organisational culture of their working milieux.

\section{Cultivating the contacts}

Clearly, the building blocks of a researcher's career need to be established internally within the institution, but certain kinds of external activity are equally essential for a successful career trajectory. Researchers must also acknowledge the importance of directing substantial efforts towards securing external sources of research funding. As one Research Associate commented: 'It was put to me in the middle of my second contract, by a rather blunt research director, that he was "not an employment agency", and that I had better start searching for external funding!'. At this point, it is worth recalling that most UK social science contract research is funded via small-scale contracts from agencies such as charities, local authorities, 
health-care trusts and the like. As previously indicated, where information about funding possibilities tends to circulate freely, researchers have the opportunity to accumulate experience of undertaking smaller projects and of dealing with funding agency contacts responsible for research. Via this process, researchers start to build a range of external personal contacts within their particular field. Once a series of research contracts has been completed satisfactorily, the researcher's centre or department develops a track record and is consequently regarded positively by funding agencies. Just as importantly for the individual researcher, s/he also begins to establish a positive reputation, which can subsequently filter through to other agencies, as one Research Fellow indicated:

'About two months ago I got rung up by someone responsible for services in __ I didn't know the person ... but they knew of me, and I got another six-month project. Last year I and a colleague completed a similar project at the other end of the county which went well. It's all about contacts and people speaking to other people about you - recommendations I suppose.' (Research Fellow, Department) 
Again, presentation of self is crucial; reputation being established not just on the basis of technical competence, but also by presenting a particular kind of persona to external agencies; a persona described by researchers as being, inter alia, enthusiastic, knowledgeable, amiable, understanding and politic. By 'understanding' researchers meant 'taking on board sponsors' constraints', or 'realising what kind of research they really want', whilst being politic was defined as 'becoming sensitive to informal agenda' and 'learning when to talk and when not to'. The presentation of an efficient self was important, but interestingly, amiability was deemed equally essential for securing research contracts from agencies. In the words of one highly experienced Senior Research Fellow: 'Sponsors want someone who is good to work with, someone they can get on with, someone with whom problems can be dealt with as smoothly as possible'. The construction of this persona usually results from trial and error and, for more fortunate researchers, gleaning from more senior colleagues the principles of good and bad practice. This permits the development of a certain degree of researcher confidence, not just in technical and organisational ability to complete contract research satisfactorily, but also in 
the effectiveness of one's network system:

'Before I had the kind of network that I have now, I used to be really fraught about getting work lined up. You know, two months to go and no work in the pipeline: help! Now I'm more confident, I feel something will turn up, and so far it always has.'

(Research Fellow, Department)

Researchers fortunate enough to find themselves in flourishing research centres, or departments with track records of gaining major research grants, are likely to engage with major players in the research sponsorship business. Within this arena, a set of contacts is established so that by the time individuals have substantial experience and/or reached the grade of Senior Research Fellow, they have usually developed considerable resources for furthering their career. The research 'universe' is never static, particularly so in relation to contract research, so therefore researchers are obliged routinely to devote time and energy to expanding their base of contacts. In research centres or particularly research-active departments, researchers used income-generating events, such as workshops or short 
courses, as a forum for parading research expertise to potential sponsors. Other somewhat instrumental ploys were utilised at national and international conferences, for example:

'When people come up to me and ask for a copy of something which I have written, I never give them a copy at the conference, particularly if they are new to me.... I always say I will send it to them, then a couple of weeks later I will send the paper plus a Centre brochure with a nice letter. That way it makes more of a lasting impression. I think it's about people realising you are dependable, you delivered in a small way. I have picked up no end of work this way.

(Senior Research Fellow, Centre)

In assembling a range of external contacts, researchers gain access to particular kinds of resources and benefits vital to promoting their careers. In their own terminology, researchers learn to 'cultivate sources', 'use the network', or 'work (my) contacts', in order to remind sponsors of their existence and competence, and to gain insight into the internal workings of funding bodies, their politics, policies, and future research directions. 
Whilst sponsors may be well aware of the competence of the research unit as a whole, more often contacts tend to be highly personalised, linking together specific individuals. As a result, departures of personnel from a sponsoring organisation can have deleterious consequences for a researcher's access to insider knowledge. Consequently, s/he has to strive to ameliorate the situation by creating new contacts or calling up contacts who were previously of a second order, for example:

'I had a really good relationship with $B \_$_ for nearly four years. We occasionally used to go to lunch, that sort of thing, but then she saw an opportunity and she moved very quickly. This kind of thing had happened to me years previously, so I suppose I had the experience to always put some energy towards her deputy ...That meant that I still had a good contact ...'

(Senior Research Fellow, Centre)

On occasion, as an outcome of networking, research contracts may even be obtained without enduring the formal process of public tendering, so that the work arrives by invitation, rather than via competition. Even when the 
process of formal competitive tendering has to be followed, it can be greatly assisted by insider information, for example about the kind of project most liable to secure funding and, just as critically, the most auspicious moment to submit the bid. In a real sense, the function of networking is intelligencegathering in order to aid researchers in the formulation of bids and the development of a sense of timing (Goodridge, 1999: 45).

\section{Generating Momentum}

Just as researchers follow the 'event-based cycle' (Clark, 1985) of each individual research contract, the most successful of their number also inhabit another cyclical process: one geared to securing their occupational future. The interviews revealed some degree of proactivity, by all except the most novice of researchers, towards gaining further contracts. However, it was evident that the interviewees who had attained the most senior grade available (Senior Research Fellow), and/or had a decade of experience, were engaged in efforts which were both habitual and systematic, and very much embedded within their normal work routines. Additionally, these individuals also tended to possess a much longer-term strategic vision (Crow, 1989) than their colleagues with less research-career 
longevity:

'When you are inexperienced at this kind of research you just focus on getting another contract... Now it's different, I have a lot of experience of bringing in contracts ... What this means is I now tend to be able to plan further into the future... Well, for example, I am negotiating over a project which should run for a year, but I also know that on the back of that project there is likely to be another one in the same area. ...I know something about their (sponsor's) long-term aims and to accomplish them they would need that kind of work done. That means having an early look at any literature around on the likely direction of a follow up.'

(Senior Research Fellow, Centre)

This strategic vision encompasses not just future policy directions, but also research trends, topics in vogue with funders, and the likely 'shelf-life' of interest in those areas: 'You learn to get a feel for when an area of research is fashionable with agencies, and you also learn to get a feel for when their interest is starting to dry up' (Research Fellow). 
As researchers develop the interactional competencies which allow them successfully to ply their trade, they simultaneously deploy these in order to secure further funded research. In this way, the momentum required to sustain a career is generated: relationships in-house and externally are established, contacts are developed and exploited, contracts secured, reputations established, and as a consequence, further contracts obtained.

\section{Conclusion}

Although a relatively small proportion of contract researchers do manage to sustain anything approximating a career, the vast majority find themselves unable to tolerate its economic marginality (Bilson, 1988). If the material and psychological insecurity cannot be tolerated, then no amount of research expertise and acumen will sustain individuals' commitment (Becker, 1977) to their occupation. The more experienced researchers identified the salient factors which they considered had rendered them able to endure such insecurity. Of considerable significance was a lack of economic dependants for extended periods of time, often when the researchers were relatively young and/or prior to the weighty 
responsibilities of family, mortgage, and so on. A further salient biographical factor was the support of a significant other (usually a husband, wife, or partner) who enjoyed a more permanent and adequate salary. Without exception, all the interviewees who had managed to sustain a relatively long career, had one or both of these factors present in their biography. This, combined with expertise developed out of considerable experience, permitted their continued work in the contract research milieu.

As has been noted, staying in contract research requires of researchers a dual learning process: first, the assimilation of the technical aspects of research, much of which is done 'on-the-job'; and second, very importantly, the development of a stock of 'informal' knowledge concerning the instrumental, political work necessary to pursue contract research successfully. It is on the basis of this latter knowledge that lines of action are developed, implemented and refined by researchers, as they seek to adapt to the pressurised and sponsor-driven environment within which they work. Such lines of action constitute some of the central craft practices (Mills, 1975) of contract research work. Precisely how successfully individuals managed to devise and implement these practices and thus 
sustain a 'career' (Hughes, 1959), appeared to depend upon three principal factors. First, there were biographical elements which influenced both the degree of craft acumen and the capacity to tolerate economic, subcultural and psychological marginality. Undoubtedly, individuals differ in the degree of receptivity to acquiring different kinds of knowledge (cf Miller and Parlett, 1976). 'Veteran' researchers all acknowledged the importance of becoming attuned to the significance of 'unofficial' activity early on in their research careers. Second, the locations in which researchers worked were highly influential in securing further employment. Well-established research centres, or departments with a strong research emphasis, clearly provide greater opportunities for establishing networks of contacts, both internal and external, which then furnish greater opportunities for securing contracts and building a positive reputation. A high correspondence was noted between suffering intermittent periods of inter-contract unemployment and working as a lone researcher in a department without a peer network. Clearly, sustaining employment depends upon learning to avoid, whenever possible, working in isolated contexts.

Third, in analysing the data it became evident that when researchers with 
relative occupational longevity strove to account for their success in maintaining employment, they consistently spoke of the importance of serendipity or happenstance in providing opportunities (Miller, 1983; Hodkinson and Sparkes, 1997). These opportunities ranged over various factors, from having the right amount of experience in a new, emergent field just as major funding opportunities arose, to the possession of linguistic competence in a foreign language required to clinch a contract, or joining a research centre at the start of a sequence of major research contracts. The occurrence of such opportunities was viewed by researchers as influential in the generation of the momentum required to spur career development.

As has been noted, contract researchers can be deemed 'unfaculty' (Kerr, 1964) in the sense of being essentially temporary, not 'real' members. This marginality is reflected in their inferior remuneration, conditions of service and status. In the face of such disadvantages, they struggle to sustain employment in an increasingly insecure occupational realm, utilising the knowledge and skills depicted in this paper. The fact that a small minority do manage to achieve this objective for extensive periods of time, 
constitutes both a victory in the face of considerable odds, and an indicator of the sophistication of their craft practice. For the majority of contract researchers, however, the insecurity and marginal conditions prove too negative to tolerate on a long-term basis. Consequently, their hard-won skills and knowledge are lost to the higher education sector, as researchers are forced to quit the occupation. Despite a national Concordat (CVCP, 1996) on improving the career management of contract researchers in the UK, and subsequent follow-up reports of the Research Careers Initiative (OST, 1998, 2000, 2001), although very small numbers of British universities have moved to transfer researchers to permanent contracts, there are no real indications that significant numbers of employers intend fundamentally to change their employment practices (Bryson, 1999; Bryson and Barnes, 2000). The irony is, of course, that whilst the policy of using short-term contracts appears to be motivated by employers' desire to cut costs, the real or hidden costs, in terms of researcher alienation, mistrust, decreased commitment and deleterious consequencies for the quality of research output, seem to have been omitted from the equation. 
Table 1: Profile of contract researchers studied $(\mathrm{N}=61)$

\begin{tabular}{|l|l|l|l|l|}
\hline Gender & Female & Male & & \\
\hline & 37 & 24 & & \\
\hline Age & $20-30$ & $31-40$ & $41-50$ & $50+$ \\
\hline Qualifications & 17 & 18 & 20 & 6 \\
\hline & First degree & Master's & Doctorate & $\begin{array}{l}\text { Professional/ } \\
\text { other }\end{array}$ \\
\hline Grade/Title & $\begin{array}{l}\text { Research } \\
\text { Assistant }\end{array}$ & $\begin{array}{l}\text { Research } \\
\text { Associate }\end{array}$ & $\begin{array}{l}\text { Research } \\
\text { Fellow }\end{array}$ & $\begin{array}{l}\text { Senior } \\
\text { Research } \\
\text { Fellow }\end{array}$ \\
\hline & 14 & 12 & $30^{*}$ & 4 \\
\hline $\begin{array}{l}\text { Experience of } \\
\text { CR }\end{array}$ & $1-3$ years & $4-6$ years & $>6$ years & \\
\hline & 25 & 16 & 20 & \\
\hline
\end{tabular}

* plus one currently unemployed Research Fellow 


\section{Note}

1. The author would like to extend thanks and appreciation to her coresearcher on the project, John Hockey, for perennial, helpful sociological insights. Grateful thanks also to Barbara Muldowney for her excellent transcription services.

\section{References}

Abbas, A. and McLean, M., (2001), 'Becoming sociologists: professional identity for part-time teachers of university sociology', British Journal of Sociology of Education, 22 (3): 339-352.

Adler, P., (1981), Momentum: a theory of social action, Sage: Beverley Hills.

Allen-Collinson, J (2000), 'Social science contract researchers in higher education: Perceptions of craft knowledge, Work, Employment \& Society, 14 (1): 159-171.

Allen-Collinson, J. and Hockey, J., (1998), 'Capturing contracts: Informal activity among contract researchers', British Journal of Sociology of Education, 19 (4): 497-515.

Association of University Teachers (AUT), (1990), Goodwill Under Stress: Morale in UK Universities, London: AUT.

Atkinson, P. and Delamont, S., (1990), 'Professions and powerlessness: female marginality in the learned occupations', Sociological Review, 38: 9110.

Barlow,K., (1995), 'Higher education as a form of labour market reform', in Smyth, J. (ed.), Academic Work: The changing labour process in Higher Education, Buckingham: SRHE/Open University Press.

Barrow, C.W., (1995), 'Beyond the Multiversity: Fiscal crisis and the 
changing structure of academic life, in Smyth, J. (ed.), Academic Work: The changing labour process in Higher Education, Buckingham: SRHE/Open University Press.

Becker, Howard S., (1977), Sociological Work: Method and Substance, Transaction Books: New Brunswick, N.J.

Berger, P. and Luckman, T., (1976), The Social Construction of Reality, Penguin: Harmondworth.

Bilson, J.M., (1988), 'No owner of soil: The concept of marginality revisited on its sixtieth birthday', International Review of Modern Sociology, 18: 183204.

Blaxter, L., Hughes, C. and Tight, M., (1998), Telling it how it is: Accounts of academic life, Higher Education Quarterly, 52 (3): 300-315.

Bourdieu, P., (1977), Outline of a Theory of Practice (trans. Nice, R.), Cambridge: Cambridge University Press.

Bryson, C., (1999), 'Contract research: the failure to address the real issues', Higher Education Review, 31 (2): 29-49.

Bryson, C. and Barnes, N., (2000), 'The Casualisation of employment in United Kingdom Higher Education', in Tight, M. (ed.), Academic Work and Life: What It Is To Be An Academic, And How This Is Changing, JAl: Amsterdam.

Bryson, C. and Tulle-Winton, E., (1994), A Survey of Contract Research Staff in UK Universities, London: AUT.

Burgess, R. G., (1984), In the Field, London: Routledge.

Burgess, R. G., (1994), 'Scholarship and sponsored research: contradiction, continuum or complementary activity?', in Halpin, D. and Troyna, B. (eds), Researching Education Policy: ethical and methodological issues, London: Falmer Press. 
Clark, P.A., (1985), 'A review of the theories of time and structure for organizational sociology', in Bacharach. S. B. and Mitchell, S. M., (eds), Research in the Sociology of Organisations, Greenwich, CT: JAI.

Committee of Vice-Chancellors and Principals (CVCP), (1996), A Concordat to Provide a Framework for the Career Management of Contract Research Staff in Universities and Colleges, London: CVCP.

Court, G., Rick, J., Dench, S., La Valle, I. and Moralee, J. (1996), Equal Opportunities in Social Science Research Careers, Brighton: Institute for Employment Studies.

Creswell, J.W., (1998), Qualitative Inquiry and Research Design, London: Sage.

Crow, G., (1989), 'The use of the concept "strategy" in recent sociological literature', Sociology, 23 (1): 1-24.

Delamont, S., (1996), 'Just like the novels? Researching the occupational culture(s) of higher education', in: Cuthbert, R. (ed.), Working in Higher Education, Buckingham: SRHE/Open University Press.

Delamont, S. and Atkinson, P., (1995), Fighting Familiarity: essays on education and ethnography, Cresskill, NJ: Hampton Press.

Delamont, S., Parry, O., Atkinson, P. and Hiken, A., (1994), 'Suspended between two stools: doctoral students in British higher education', in: Coffey, A. and Atkinson, P. (eds), Occupational Socialisation and Working Lives, Aldershot: Avebury.

Dornbusch, S.M., (1955), 'The military academy as an assimilating institution', Social Forces, 33: 316-321.

Edwards, R., (2000), 'Numbers are not enough: Women in Higher Education and being a feminist academic', in: Tight, M. (ed.), Academic Work and Life: What it is to be an Academic and How this is Changing, JAI: 
Amsterdam.

Evetts, J., (1992), 'Dimensions of career: avoiding reification in the analysis of change', Sociology, 26 (1): 1-21.

Freedman, E.S., Patrick, H., Somekh, B., Mclntyre, M. and Wikeley, F. (2000), Quality Conditions for Quality Research: Guidance for Good Practice in the Employment of Contract Researchers in Education, Southwell, Notts: British Educational Research Association.

Gerholm, T., (1990), 'On tacit knowledge in academia', European Journal of Education, 25: 263-271.

Glaser, B., (1993), Basics of Grounded Theory Analysis, Mill Valley, CA: Sociology Press.

Goffman, E., (1959), The Presentation of Self in Everyday Life, New York: Anchor.

Goodridge, J., (1999), Rhythm and Timing of Movement and Performance, London: Jessica Kingsley.

Harvey, D., (1989), The Condition of Postmodernity, Oxford: Basil Blackwell.

Hassard, J., (1989), 'Time and industrial sociology', in: Blyton, P. Hassard, J., Hill, J. and Starkey, K., Time, Work and Organisation, London: Routledge.

Hey, V., (2001), 'The construction of academic time: Sub/contracting academic labour in research', Journal of Education Policy, 16 (1): 67-84.

Hodkinson, P. and Sparkes, A.C., (1997), 'Careership: a sociological theory of career decision making', British Journal of Sociology of Education, 18 (1): 29-44.

Hughes, E.C., (1959), 'The Study of occupations' in: Merton, R.K., Broomand, L. and Cotrell, L. (eds), Sociology Today, New York: Basic 
Books.

Her Majesty's Stationery Office (HMSO), (1998) Independent Review of Higher Education Pay and Conditions, Norwich: HMSO.

Kerr, C., (1964), The Uses of the University, Cambridge, Mass: Harvard University Press.

Kleinman, S., (1983), 'Collective matters as individual concerns: peer culture among graduate students', Urban Life, 12: 203-225.

Kogan, M., Moses, I. and El-Khawas, E. (1994) Staffing Higher Education: Meeting New Challenges, London: Jessica Kingsley.

Lane, C., (1989), 'From "Welfare Capitalism" to "Market Capitalism": A Comparative review of trends towards employment flexibility in the labour markets of three major European societies', Sociology, 23 (4): 583-610.

Lauer, Robert H., (1981), Temporal Man: The meaning and uses of Social Time, New York: Praeger.

Lee, H. and Liebenau, J., (1999), 'Time in organizational studies: Towards a new research direction', Organization Studies, 20 (6): 1035-1058.

Loft, A., (1995), 'Time is money', Studies in Culture, Organizations and Society, 1, 127-145.

Mauss, M., (1967), The Gift: Forms and functions of exchange in archaic societies (trans. Cunison, I.), New York: W.W. Norton.

Mayne, L., Tregaskis, O. and Brewster, C., (1996), 'A Comparative analysis of the link between flexibility and HRM strategy', Employee Relations, 81 (3): 5-19.

McCalman, J., (1996), Towns and Gowns: The Humanities and the Community, Bendigo: La Trobe University.

Mclnnis, C., (2000), 'Towards New Balance or New Divides? The changing 
work roles of academics in Australia', in Tight, M. (ed.) Academic Work and Life: What It is To Be An Academic, And How This Is Changing, Amsterdam: JAI Press.

Miller, C. M. L. and Parlett, M., (1976), 'Cue-consciousness', in Hammersley, M. and Woods, P., (eds), The Process of Schooling, London: Routledge \& Kegan Paul.

Miller, M., (1983), 'The role of happenstance in career choice', Vocational Guidance Quarterly, 32: 16-20.

Mills, C.W., (1975), The Sociological Imagination, Harmondsworth: Penguin.

Mitchell, J.C., (1983), 'Case and situation analysis', Sociological Review, 31: 187-211.

Morse, J.M., (1994), 'Designing funded qualitative research', in: Denzin, N. K. and Lincoln, Y. S. (eds), Handbook of Qualitative Research, Thousand Oaks, CA: Sage.

Office of Science and Technology (OST) (1998), Research Careers Initiative Report, October 1998, London: OST.

Office of Science and Technology (OST) (2000), Research Careers Initiative 2nd Report, May 2000, London: OST.

Office of Science and Technology (OST) (2001), Research Careers Initiative $3^{\text {rd }}$ (Interim) Report, September 2001, London: OST.

Norris, N., (1991), A Survey of the Terms and Conditions of Contract Research Workers in UK Universities, Norwich: Centre for Applied Research in Education, UEA.

Parker, M. and Jary, D., (1995), 'The McUniversity: Organization, management and academic subjectivity', Organization, 2 (2): 319-338.

Patrick, H., (1998), Contract Researchers in education: a review of the 
literature, Paper presented at the BERA Conference, Belfast, August.

Pirrie, A., (1997), 'The new game: Professional foul or own goal?', British Educational Research Journal, 23: 565 -574.

Polanyi, M., (1983), Personal Knowledge, London: Routledge.

Pole, C. J. (1995), 'Don't shoot the messenger: A study in the politics and control of funded research', Evaluation and Research in Education, 9, 135148.

Rees, T., (1985), Control and Funding of Research in British Universities: the Effects on Contract Research Staff, Cardiff: University of Wales, Social Research Unit.

Roberts, Sir Gareth (2002), SET for Success. The supply of people with science, technology, engineering and mathematics skills. The report of Sir Gareth Roberts' Review, London, HM Treasury.

Roth, J. (1966), 'Hired hand research', American Sociologist, 1, 190-196.

Rubery, J. and Grimshaw, D. (2003), The Organization of Employment: an international perspective, Basingstoke: Palgrave Macmillan.

Scott, S. (1985), 'Working through the contradictions in researching postgraduate education', in: Burgess, R. G. (ed.), Field Methods in the Study of Education, Lewes: Falmer.

Scott, S. and Porter, M. A. (1983), 'On the bottom rung: A discussion of women's work in sociology', Women's Studies International Forum, 6, 211221.

Scott, S. and Porter, M. A. (1984), 'The double marginalisation of women in research', in: Acker, S. and Warren-Piper, D. (eds), Is Higher Education Fair to Women?, Guildford: SRHE/NFER-Nelson.

Shumar, W., (1997), College for Sale: A Critique of the Commodification of 
Higher Education, London: Falmer.

Slaughter, S. and Leslie, L., (1997), Academic Capitalism: politics, policies, and the entrepreneurial university, Baltimore: Johns Hopkins University Press.

Smith, R.B., (1991), 'Patterns of a lost generation: Adaptations of PhDs to restricted academic opportunities', American Sociologist, 22: 85-108.

Stronach, I. and MacDonald, B. (1991), Faces and Futures: an inquiry into the jobs, lives and careers of educational researchers in an ESRC Initiative, Norwich: Centre for Applied Research in Education, UEA.

Varlaam, C., (1988), Contract Researchers: The Human Resource. IMS Report No 163, Brighton: Institute of Manpower Studies.

Wakeford, J. (1985), 'A director's dilemma', in: Burgess, R. G. (ed.), Field Methods in the Study of Education, Lewes: Falmer.

Wasser, H., (1990), 'Changes in the European University: From traditional to entrepreneurial', Higher Education Quarterly, 44: 111-122.

Whiston, T., (n.d), Contract Researchers and the Social Sciences: An ESRC Review of Research Careers: Research Investment, Falmer, Brighton: Science Policy Research Unit, University of Sussex.

Wolcott, H.F., (1995), The Art of Fieldwork, London: Sage.

Wunsch, M.A., (1993), Mentoring probationary women academics: A pilot programme for career development, Studies in Higher Education, 18: 349362.

Ziman, J., (1991), 'Academic science as a system of markets', Higher Education Quarterly, 45: 41-61. 